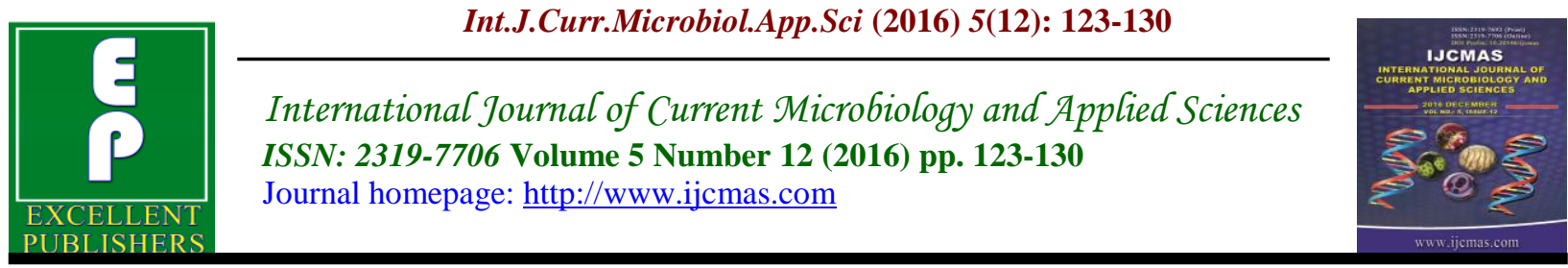

Review Article

http://dx.doi.org/10.20546/ijcmas.2016.512.014

\title{
A Review Paper on Properties of Fungal Lipases
}

\author{
Arun Kumar Sharma ${ }^{1}$, Vinay Sharma ${ }^{1}$ and Jyoti Saxena ${ }^{2}$ \\ ${ }^{1}$ Department of Bioscience and Biotechnology, Banasthali University, Rajasthan, India \\ ${ }^{2}$ Department of Biochemical Engineering, Bipin Tripathi Kumaon Institute of Technology, \\ Dwarahat, Uttrakhand, India \\ *Corresponding author
}

\section{A B S T R A C T}

Keywords

Enzymes, fungal lipases, extracellular, pitch, $\mathrm{pH}$, metal ions, application, stability.

\section{Article Info}

Accepted:

08 November 2016

Available Online:

10 December 2016
Enzymes are believed catalysts of nature. Lipases are multifaceted enzymes that are utilized broadly. Lipases exist broadly in nature, but only microbial lipases are industrially important. In last few years, fungal lipases gained important consideration in the industries because of their specificity to substrate and stability under different physical and chemical situations. Fungal enzymes are secreted extracellularly and they can be purified simply, which considerably decreases the cost and makes this source superior over bacteria. The several applications of lipases include hydrolysis of oils and fats, flavor development in food processing, modification of fats, resolution of racemic mixtures, removal of oil strains from clothes, estimation of amount of triacylglycerol in the person serum, removal of pitch from timber during paper manufacturing and chemical analysis. An elaborated study of lipase properties makes possible its application in appropriate industrial processes. So by keeping the huge applications of lipases in mind, the current review is focused on properties such as activity and stability profile in various $\mathrm{pH}$ and temperature, impacts of metal ions and stability in organic solvents.

\section{Introduction}

Lipases have appeared as one of the important biocatalysts with definite potential for contributing to the billion dollar underexploited lipid technology bio-industry and have been utilized in in situ metabolism of lipid and ex situ versatile industrial applications (Sharma and Kanwar, 2012). Lipases are triaclyglycerol acylhydrolases that catalyze the hydrolytic cleavage of ester bonds present within the triaclyglycerol into fatty acids and glycerol. They usually show additional activities such as cutinase, phospholipase, cholesterol esterase, isophospholipase, amidase and other esterase kind of activities (Svendsen, 2000). Lipases are excreted by every class of living organisms but microbial lipases have gained special attention of industries because of their simple extraction procedures, unlimited supply, capability towards extremes of $\mathrm{pH}$, temperature, metal ions, organic solvents, and chemo-, region-, and enantioselectivity (Thakur, 2012). The lipases are as imperative industrially as the amylases and proteases.

Amongst the different microorganisms identified as source of lipases, filamentous 
fungi are believed as the excellent source of extracellular lipase for mass production at industrial level. High cost of lipase production is a main problem in its application in industrial processes. Thus, a variety of efforts have been made to decrease its production cost (Smaniotto et al., 2012). Fungi are generally chosen as lipase producers since they produce extracellular enzymes that can be simply separated from the fermentation media (Maia et al., 1999). Mainly, species belonging to Penicillium, Mucor, Rhizopus, Aspergillus and Geotrichum are broadly identified as excellent source of lipase (Carvalho et al., 2005; Contesini et al., 2010). Amongst them numerous species of Aspergillus, isolated from terrestrial sources, have been documented to excrete lipase with notable properties fit for biotechnological applications (Basheer et al., 2011; Sharma et al., 2016). Physico-chemical properties of several extracellular fungal lipases have been determined. Numerous lipases have been carefully purified and characterized in terms of their stability and activity profiles relative to temperature, $\mathrm{pH}$, and impacts of metal ions, organic solvents and chelating agents (Jayaprakash and Ebenezer, 2012). Therefore, the present review is focused on properties of microbial lipases.

\section{Characterization of extracellular lipases}

Some exclusive features of lipases such as their substrate specificity, $\mathrm{pH}$ and temperature dependency, stability in organic solvents, activity in metal ions and nontoxic nature leads to their main role in the food processing industries (Verma et al., 2012). The most preferred characteristics of the lipases are their capability to use all mono-, di-, and tri-acylglycerides as well as the free fatty acids in transesterification, little inhibition by product, high activity/yield in non-aqueous media, little reaction time, resistant to altered $\mathrm{pH}$, temperature, organic solvents and metal ions (Kumar et al., 2012a). Sumathy et al., (2012) have reported that lipase purified from A. niger had molecular weight of $40 \mathrm{kD}$.

\section{Impact of temperatures on activity and stability of lipase}

Falony et al., (2006) investigated impact of various temperatures $\left(20-90{ }^{\circ} \mathrm{C}\right)$ on the activity of lipase by A. niger. Enzyme was highly active at $40{ }^{\circ} \mathrm{C}$ and then lipase activity was started to decline drastically after $60^{\circ} \mathrm{C}$. Enzyme activity was completely lost at $90{ }^{\circ} \mathrm{C}$. Sarkar and Laha (2013) reported that lipase of A. niger exhibited maximum activity $\left(0.40 \mathrm{U} \mathrm{ml}^{-1}\right)$ at $40{ }^{\circ} \mathrm{C}$. Jayaprakash and Ebenezer (2012) studied influence of various temperatures $\left(20-90{ }^{\circ} \mathrm{C}\right)$ on the activity and stability of lipase purified from A. japonicus. An optimum temperature of $40{ }^{\circ} \mathrm{C}$ was found, that was followed by reduction in the lipase activity with rise in temperature and activity reached to minimum at $90{ }^{\circ} \mathrm{C}$. In the stability pattern, lipase remained stable in the temperature range of $30-60{ }^{\circ} \mathrm{C}$ when pre-incubated for 1 h. Ulker et al., (2011) depicted an optimum temperature of $40{ }^{\circ} \mathrm{C}$ for the maximum activity of lipase from $T$. harzianum. Lipase activity was reduced by changing the temperature optima, while in the stability profile, enzyme remained stable at the temperature range of $20-40{ }^{\circ} \mathrm{C}$, after preincubation for $1 \mathrm{~h}$. However activity of lipase was completely lost at high temperature range from $60-80^{\circ} \mathrm{C}$.

Pera et al., (2006) demonstrated activity of A. niger lipase within the temperature range of $4-55^{\circ} \mathrm{C}$. Among all temperatures, optimum activity was found at $37{ }^{\circ} \mathrm{C}$ while in the temperature stability profile, enzyme remained stable in the temperature range of $30-55{ }^{\circ} \mathrm{C}$ with highest stability at $37{ }^{\circ} \mathrm{C}$ 
when pre-incubated for $1 \mathrm{~h}$. Similarly, an optimum temperature of $37^{\circ} \mathrm{C}$ for activity of lipase has been documented by other workers (Kamini et al., 1998; Saxena et al., 2003). However, Essamri et al., (1998) manifested that lipase of $R$. oryzae exhibited optimum activity at $30{ }^{\circ} \mathrm{C}$. Kalindhi and Vijayalakshmi (2015) reported that purified lipase of fungus $E$. ashbyii demonstrated optimum activity at $30^{\circ} \mathrm{C}$ with $\mathrm{pH}$ of 7.0.

Maia et al., (1999) revealed an optimum temperature of $25^{\circ} \mathrm{C}$ for activity of lipase by $F$. solani. Lipase activity was decreased above the optimum temperature and reached to zero at $60{ }^{\circ} \mathrm{C}$ while in the stability pattern, highest stability was detected in the temperature range of $25-30{ }^{\circ} \mathrm{C}$ after preincubation for $1 \mathrm{~h}$. Enzyme became inactivated at temperature above $40{ }^{\circ} \mathrm{C}$. Shu et al., (2006) reported that lipase of Antrodia cinnamomea retained stability within the temperature range of $25-60{ }^{\circ} \mathrm{C}$ with maximum stability at $45^{\circ} \mathrm{C}$. Ranjitha et al., (2009) reported that the lipase of $V$. fischeri retained $80 \%$ of its activity at $35^{\circ} \mathrm{C}$, but the lower residual activities were found at $5^{\circ} \mathrm{C}$, $10{ }^{\circ} \mathrm{C}$ and $50{ }^{\circ} \mathrm{C}$. Kumar et al., (2012b) demonstrated that purified lipase of $B$. pumilus RK31 was found stable at $40{ }^{\circ} \mathrm{C}, 50$ ${ }^{\circ} \mathrm{C}$ and $60{ }^{\circ} \mathrm{C}$ retaining the $66 \%, 66 \%$ and $69 \%$ residual activities.

\section{Impact of $\mathbf{p H}$ on lipase activity and stability}

Falony et al., (2006) studied influence of various $\mathrm{pH}$ on the activity of $A$. niger lipase. In the activity pattern, highest lipase activity was obtained at $\mathrm{pH} 6.0$ among the all $\mathrm{pH}$ (4.0-10.0). In the stability profile, the lipase was stable and retained $100 \%$ of its activity within the $\mathrm{pH}$ range of 4.0 to 7.0 for $24 \mathrm{~h}$. Lipase stability was declined after $\mathrm{pH} 7.0$ and reached to minimum at $\mathrm{pH}$ 10.0. Similar results were obtained by Sarkar and Laha
(2013). Pera et al., (2006) depicted that lipase of $A$. niger MYA 135 was active within the $\mathrm{pH}$ range of $2.0-10.0$ but optimum activity was obtained at $\mathrm{pH} 6.5$, while in the $\mathrm{pH}$ stability pattern, lipase retained its activity within the $\mathrm{pH}$ range of 2.0-10.0 when pre-incubated for $1 \mathrm{~h}$ at 37 ${ }^{\circ} \mathrm{C}$. Sugihara et al., (1988) previously reported that the lipase secreted by $A$. niger demonstrated its highest activity between $\mathrm{pH} 4.5$ to 5.5 at $25{ }^{\circ} \mathrm{C}$ and retained its stability in the $\mathrm{pH}$ range from 3.0 to 10.5 at $30{ }^{\circ} \mathrm{C}$ for $24 \mathrm{~h}$. For maximum activity of lipase, an optimum $\mathrm{pH}$ of 2.5 for $A$. niger (Mahadik et al., 2002), $\mathrm{pH}$ of 6.5 for $A$. niger (Kamini et al., 1998), and $\mathrm{pH}$ of 9.0 for A. carneus (Saxena et al., 2003) has been reported.

Jayaprakash and Ebenezer (2012) investigated influence of different $\mathrm{pH}$ (3.012.0) on the activity and stability of lipase purified from $A$. japonicus. In the activity profile, $\mathrm{pH} 7.5$ was the best for highest activity of lipase followed by reduction in the activity with rise in the $\mathrm{pH}$ and the activity was completely lost at $\mathrm{pH} 12.0$. In the stability profile, the enzyme retained stability in the $\mathrm{pH}$ range of 6.5-8.0 when incubated for $24 \mathrm{~h}$. Costa and Peralta (1999) earlier manifested that optimum temperature and $\mathrm{pH}$ for activity of lipase by $P$. wortmanii were $45{ }^{\circ} \mathrm{C}$ and 7.0, respectively. An optimum temperature and $\mathrm{pH}$ for the activity of $A$. oryzae lipase were found to be $30^{\circ} \mathrm{C}$ and 7.0, respectively (Toida et al., 1995).

Maia et al. (1999) reported that among the all tested $\mathrm{pH}$ (6.0-9.0), optimum activity of lipase by $F$. solani was found at $\mathrm{pH}$ 8.6. Lipase activity was decreased in the $\mathrm{pH}$ values below 8.5 and reached to minimum at 6.5 , indicating alkaline nature of lipase. In the $\mathrm{pH}$ stability profile, lipase retained $80 \%$ of its activity in the $\mathrm{pH}$ range of 7.2-8.6 with the highest stability at $\mathrm{pH} 7.2$ when pre- 
incubated for $1 \mathrm{~h}$. Ulker et al., (2011) reported that $\mathrm{pH} 8.5$ was found to be the excellent for maximum activity of lipase by T. harzianum. Lipase activity was declined by changing the $\mathrm{pH}$ above or below the $\mathrm{pH}$ optima.

In case of lipase stability, the enzyme was found highly stable at $\mathrm{pH}$ optima and retained $70 \%$ of its activity within the $\mathrm{pH}$ range of 8.0-11.0, after pre-incubation of 24 h. Hoshino et al., (1992) also demonstrated highest stability of $F$. oxysporum lipase at alkaline pH. Shu et al., (2006) reported that lipase of Antrodia cinnamomea was found stable within the alkaline $\mathrm{pH}$ range of 7.010.0 with maximum activity at $\mathrm{pH}$ 8.0.

Both the enzyme activity and stability were declined considerably in the $\mathrm{pH}$ values above 10.0. An optimum activity of $R$. oryzae lipase within the alkaline $\mathrm{pH}$ range has been documented by Minning et al., (1998). Costa-Silva et al., (2014) reported that activity of extracellular lipase of fungus Cercospora kikuchii was not lost when kept in the $\mathrm{pH}$ range of 3.0-9.0.

Amoozegar et al., (2008) and Kasana et al., (2008) reported stability of lipase enzyme within the $\mathrm{pH}$ range of 7.5-8.0. The enzyme also retained $90 \%$ of its activity. Ranjitha et al. (2009) reported maximum stability (residual activity) of purified bacterial lipase at pH 8.0. Kumar et al., (2012c) revealed highest and lowest activity of purified lipase by Bacillus sp. HPE 10 at $\mathrm{pH} 6.0$ and $\mathrm{pH}$ 8.0, respectively. Other lipases exhibited stability in the $\mathrm{pH}$ range of 5.5 to 9.0 (Fox and Stepaniak, 1983).

Zhang and Zhang (1982) reported that the purified lipase preparation retained stability within the alkaline range of $\mathrm{pH}$ from 7.0 to 10.0 justified it to be a potent alkaline lipase in the degreasing process in leather industry.

\section{Impact of organic solvents on stability of lipase}

Pera et al., (2006) studied impact of various water miscible solvents (methanol, ethanol, acetone, butanol, hexane and heptane) on the stability of $A$. niger lipase. The enzyme was found stable in all organic solvents with highest residual activity in acetone when pre-incubated for $1 \mathrm{~h}$ at $37{ }^{\circ} \mathrm{C}$. Lowest residual activity was obtained with heptanes. Jayaprakash and Ebenezer (2012) investigated influence of different organic solvents (at a concentration of $10 \%$ and $20 \%$ $\mathrm{v} / \mathrm{v})$ on the stability of purified lipase of $A$. japonicus. The enzyme retained $90 \%$ of its activity in methanol, acetone, chloroform, ethanol and hexane with highest residual activity $(95 \%)$ in methanol $(10 \% \mathrm{v} / \mathrm{v})$ when pre-incubated for $1 \mathrm{~h}$. Reduction in lipase stability was noticed with the rise in concentration of organic solvents from $10 \%$ to $20 \%$. It was reported by Maia et al., (1999) that lipase of $F$. solani retained $30 \%$ of its activity in acetone and n-propanol $(10 \% \mathrm{v} / \mathrm{v})$ while $20 \%$ concentration of both solvents completely suppressed lipase stability.

However, Zhou et al., (2012) reported inhibition of lipase activity by ethanol and n-butanol. It was reported that organic solvents (water miscible) shred water from the enzymes, which results in denaturation of the molecule at a much rapid rate than in a pure water system (Azevedo et al., 2001). Kumar et al., (2012b) reported highest $(120.50 \%)$ and lowest relative activity $(10 \%)$ by $B$. pumilus RK31 in petroleum ether and diethyl ether, respectively.

\section{Impact of metal ions on stability of lipase}

Jayaprakash and Ebenezer (2012) investigated impact of different metal ions 
(1 $\mathrm{mM})$ on stability of lipase purified from A. japonicus. Activity of lipase was inhibited by $\mathrm{Mn}^{2+}$ and $\mathrm{Hg}^{2+}$ while $\mathrm{Ca}^{2+}$ was found to be the best for maximum activity after pre-incubation for $1 \mathrm{~h}$. Ulker et al. (2011) reported stability of $T$. harzianum lipase after pre-incubation for $1 \mathrm{~h}$ in various metal ions $(1 \mathrm{mM}) \cdot \mathrm{Ca}^{2+}$ and $\mathrm{Mn}^{2+}$ increased the activity of lipase up to $25 \%$ and $15 \%$, respectively, while $\mathrm{K}^{+}$and $\mathrm{Cr}^{3+}$ inhibited the lipase activity by $22 \%$ and $21 \%$, respectively as compared with the control. Lipase activity was not influenced by other metal ions used in the study $\left(\mathrm{Na}^{+}, \mathrm{Ba}^{2+}\right.$, $\mathrm{Cu}^{2+}, \mathrm{Cd}^{2+}, \mathrm{Co}^{2+}$ and $\left.\mathrm{Fe}^{3+}\right)$. Katiyar and Ali (2013) reported highest increase in catalytic activity of Candida rugosa lipase by $\mathrm{Ca}^{2+}$. This might be due to the fact that the enzyme requires $\mathrm{Ca}^{2+}$ as a cofactor for its biological activity.

Kambourova et al., (2003) described that the stimulatory impact of $\mathrm{Ca}^{2+}$ is because of formation of insoluble ion-salts of fatty acids during hydrolysis, hence avoiding the inhibition of product formation. Yu et al. (2009) depicted that activity of lipase from $R$. chinensis was enhanced up to $24 \%$ by $\mathrm{Ca}^{2+}(1 \mathrm{mM})$ while on the other hand, Ohnishi et al. (1994) reported that activity of A. oryzae lipase was inhibited up to $77 \%$ by $\mathrm{Ca}^{2+}(5 \mathrm{mM})$.

Toida et al., (1995) reported inhibition of activity of $A$. oryzae lipase by $\mathrm{Cu}^{2+}, \mathrm{Fe}^{3+}$, $\mathrm{Hg}^{2+}, \mathrm{Zn}^{2+}$ and $\mathrm{Ag}^{+}$. Oliveira et al. (2014) reported that $\mathrm{Na}^{+}$increased lipase stability of yeast by 5.6\%. Ghori et al. (2011) demonstrated that activity of Bacillus sp. lipase was enhanced by $\mathrm{Mg}^{2+}, \mathrm{Mn}^{2+}$ and $\mathrm{Fe}^{2+}$ while $\mathrm{Co}^{2+}, \mathrm{Cu}^{2+}$ and $\mathrm{Na}^{+}$decreased the lipase activity. Tiwari et al. (2011) reported that lipase activity was increased in presence of $\mathrm{Mg}^{2+}, \mathrm{Ba}^{2+}$ and $\mathrm{Ca}^{2+}$ while it was decreased in presence of $\mathrm{Ag}^{+}$. It was reported by Costa-Silva et al. (2014) that the ions $\mathrm{Al}^{3+}, \mathrm{Ca}^{2+}, \mathrm{Mn}^{2+}, \mathrm{Zn}^{2+}$ and $\mathrm{Hg}^{2+}$ increased the extracellular lipase activity of the fungus $C$. kikuchii. Residual lipase activity was increased to $129.30 \%$ in presence of $\mathrm{Al}^{3+}$ ion as compared to control.

Hasan et al., (2006) had previously described that metal ions have tendency to make complexes with ionized form of fatty acids, which results in changing their behaviour and solubility at interfaces. The liberation of fatty acids into the culture medium is rate determining factor, which is influenced by metal ions. However, the impact of metal ions varies and depends on the type of lipase. The activity of extracellular lipase from $R$. japonicus NR400 was not influenced in the presence of metal ions (1 mM) (Suzuki et al., 1986). Mase et al. (1995) reported that activity of lipase by $P$. roqueforti IAM7268 was not influenced by the addition of $\mathrm{Ca}^{2+}, \mathrm{Mg}^{2+}$, $\mathrm{Mn}^{2+}, \mathrm{Na}^{+}, \mathrm{K}^{+}$and $\mathrm{Cu}^{2+}$.

In conclusion, fungi are able to produce many enzymes for their continued existence within a broad variety of substrates. Among those enzymes, lipases are mainly utilized in a number of applications. The major benefit of fungal lipases is that they are simply acquiescent to separation because of their extracellular nature, which considerably decreases the overall cost and makes these lipases more interesting than bacterial lipases. A detailed characterization study (activity and stability under different $\mathrm{pH}$, temperature, metal ions and organic solvents) of fungal lipases should be done in order to determine their suitability in various industrial processes.

\section{Acknowledgments}

The authors are grateful to Professor Aditya Shastri, Vice-Chancellor, Banasthali University, Rajasthan for providing necessary research facilities. 


\section{References}

Amoozegar, M.A., Salehghamari, E., Khajeh, K., Kabiri, M. and Naddaf, S. 2008. Production of an extracellular thermohalophilic lipase from a moderately halophilic bacterium, Salinivibrio sp. strain SA-2. J. Basic Microbiol., 48(3): 160-167.

Azevedo, A.M., Prazeres, D.M.F., Cabral, J.M.S. and Fonseca, L.P. 2001. Stability of free and immobilised peroxidase in aqueous-organic solvents mixtures. $J$. Mol. Catal. B: Enzym., 15(4-6): 147153.

Basheer, S.M., Chellappan, S., Beena, P.S., Sukumaran, K., Elyas, K.K. and Chandrasekaran, M. 2011. Lipase from marine Aspergillus awamori BTMFW032: Production, partial purification and application in oil effluent treatment. N. Biotechnol., 28(6): 627-638.

Carvalho, P.D.O., Calafatti, S.A., Marassi, M., da Silva, D.M., Contesini, F.J., Bizaco, R. and Macedo, G.A. 2005. Potential of enantioselective biocatalysis by microbial lipases. Quim. Nova., 28(4): 614-621.

Contesini, F.J., Lopes, D.B., Macedo, G.A., Nascimento, M.D.G. and Carvalho, P.D.O. 2010. Aspergillus sp. lipase: Potential biocatalyst for industrial use. J. Mol. Catal. B Enzym., 67(3-4): 163171.

Costa, M.A. and Peralta, R.M. 1999. Production of lipase by soil fungi and partial characterization of lipase from a selected strain (Penicillium wortmanii). J. Basic Microbiol., 39(1): 11-15.

Costa-Silva, T.A., Souza, C.R.F., Oliveira, W.P. and Said, S. 2014. Characterization and spray drying of lipase produced by the endophytic fungus Cercospora kikuchii. Braz. J. Chem. Eng., 31(4): 849-858.

Essamri, M., Deyries, V. and Comeau, L. 1998. Optimization of lipase production by Rhizopus oryzae and study on the activity in organic solvents. $J$. Bacteriol., 60(1-2): 97-103.

Falony, G., Armas, J.C., Mendoza, J.C.D. and Hernandez, J.L.M. 2006. Production of Extracellular Lipase from Aspergillus niger by Solid-State Fermentation. Food Technol. Biotechnol., 44(2): 235-240.

Fox, P.F. and Stepaniak, L. 1983. Isolation and some properties of extracellular heat- stable lipases from Pseudomonas fluorescens strain AFT 36. J. Dairy Res., 50(1): 77-89.

Ghori, M.I., Iqbal, M.J. and Hameed, A. 2011. Characterization of a novel lipase from Bacillus sp. isolated from tannery wastes. Braz. J. Microbiol., 42(1): 2229.

Hasan, F., Shah, A.A. and Hameed, A. 2006. Industrial applications of microbial lipases. Enzyme Microb. Technol., 39(2): 235-251.

Hoshino, T., Sasaki, T., Watanabe, Y., Nagasawa, T. and Yamane, T. 1992. Purification and some characteristics of extracellular lipase from Fusarium oxysporum f. sp. lini. Biosci. Biotechnol. Biochem., 56(4): 660-664.

Jayaprakash, A. and Ebenezer, P. 2012. Purification and characterization of Aspergillus japonicus lipase from a pig fat production medium. J. Acad. Indus. Res., 1(1): 1-7.

Kalindhi, K. and Vijayalakshmi, S. 2015. Isolation and Purification of Lipase from the Riboflavin Overproducing Fungus Eremothecium Ashbyii. $J$. Analg., 3(1): 1-8.

Kambourova, M., Kirilova, N., Mandeva, R. and Derekova, A. 2003. Purification and properties of thermostable lipase from a thermophilic

Bacillus stearothermophilus MC 7. J. Mol. Catal. B: Enzym., 22(5-6): 307-313.

Kamini, N.R., Mala, J.G.S. and Puvanakrishnan, R. 1998. Lipase production from Aspergillus niger by solid-state fermentation using gingelly oil cake. Process Biochem., 33(5): 505- 
511.

Kasana, R.C., Kaur, B. and Yadav, S.K. 2008. Isolation and identification of a psychrotrophic Acinetobacter sp. CR9 and characterization of its alkaline lipase. J. Basic Microbiol., 48(3): 207212.

Katiyar, M. and Ali, A. 2013. Effect of metal ions on the hydrolytic and transesterification activities of Candida rugosa lipase. J. Oleo Sci., 62(11): 919924.

Kumar, A., Sharma, P. and Kanwar, S.S. 2012a. Lipase catalyzed esters syntheses in organic media: A review, International Journal of Institutional Pharmacy and Life Sciences, 2(2): 91119.

Kumar, D.J.M., Priyadharshini, D.A., Suresh, K., Saranya, G.M., Rajendran, K. and Kalaichelvan, P.T. 2012c. Production, Purification and Characterization of $\alpha$ Amylase and Alkaline Protease by Bacillus sp. HPE 10 in a Concomitant Production Medium. Asian J. Plant Sci. Res., 2(3): 376-382.

Kumar, R., Sharma, A., Kumar, A. and Singh, D. 2012b. Lipase from Bacillus pumilus RK31: Production, Purification and Some Properties. World Appl. Sci. J., 16(7): 940-948.

Mahadik, N.D., Puntambekar, U.S., Bastawde, K.B., Khire, J.M. and Gokhale, D.V. 2002. Production of acidic lipase by Aspergillus niger in solid state fermentation. Process Biochem., 38(5): 715-721.

Maia, M.D.M.D., Morais, M.M.C.D., Morais, M.A.D., Melo, E.H.M. and Filho, J.L.D.L. 1999. Production of extracellular lipase by the phytopathogenic fungus Fusarium solani FS1. Rev. Microbiol., 30(4): 304309.

Mase, T., Matsumiya, Y. and Akiba, T. 1995. Purification and characterization of a new lipase from Fusarium sp. YM-30. Biosci. Biotechnol. Biochem., 59(9): 1771-1772.
Minning, S., Schmidt-Dannert, C. and Schmid, R.D. 1998. Functional expression of Rhizopus oryzae lipase in Pichia pastoris: high-level production and some properties. J. Biotechnol., 66(2-3): 147-156.

Ohnishi, K., Yohko, Y., Toita, J. and Sekiguchi, J. 1994. Purification and characterization of a novel lipolytic enzyme from Aspergillus oryzae. $J$. Ferment. Bioeng., 78(6): 413-419.

Oliveira, A.C.D., Fernandes, M.L. and Mariano, A.B. 2014. Production and characterization of an extracellular lipase from Candida guilliermondii. Braz. J. Microbiol., 45(4): 1503-1511.

Pera, L.M., Romero, C.M., Baigori, M.D. and Castro, G.R. 2006. Catalytic Properties of Lipase Extracts from Aspergillus niger. Food Technol. Biotechnol., 44(2): 247-252.

Ranjitha, P., Karthy, E.S. and Mohankumar, A. 2009. Purification and Characterization of the Lipase from Marine Vibrio fischeri. Int. J. Biol., 1(2): 48-56.

Sarkar, D. and Laha, S. 2013. Optimization of extracellular lipase enzyme production from Aspergillus niger by submerged and solid state fermentation process. Int. J. Pharma Bio Sci., 4(4): 978-985.

Saxena, R.K., Davidson, W.S., Sheoran, A. and Bhoopander, G. 2003. Purification and characterization of an alkaline thermostable lipase from Aspergillus carneus. Process Biochem., 39(2): 239247.

Sharma, A.K., Sharma, V. and Saxena, J. 2016. Isolation and Screening of extracellular lipase producing fungi from soil. Am. J. Pharm. Health Res., 4(8): 38-50.

Sharma, C.K. and Kanwar, S.S. 2012. Purification of a Novel Thermophilic Lipase from $B$. licheniformis MTCC10498, ISCA J. Biological Sci., 1(3): 4348.

Shu, C.H., Xu, C.J. and Lin, G.C. 2006. Purification and partial characterization 
of a lipase from Antrodia cinnamomea. Process Biochem., 41(3): 734-738.

Smaniotto, A., Skovronski, A., Rigo, E., Tsai, S.M., Durrer, A., Foltran, L.L., Luccio, M.D., Oliveira, J.V., de Oliveira, D. and Treichel, H. 2012. Synthetic lipase production from a newly isolated Sporidiobolus pararoseus strain. Braz. J. Microbiol., 43(4): 1490-1498.

Sugihara, A., Shimada, Y. and Tominaga, Y. 1988. Purification and characterization of Aspergillus niger lipase. Agric. Biol. Chem., 52(6): 1591-1592.

Sumathy, R., Vijayalakshmi, M. and Deecaraman, M. 2012. Studies on Lipase production from fungal strains by different inducers at varied concentrations - A comparative study. Int. J. Environ. Sci., 3(3): 1072-1078.

Suzuki, M., Yamamoto, H. and Mizugaki, M. 1986. Purification and general properties of a metal-insensitive lipase from Rhizopus japonicus NR 400. J. Biochem., 100(5): 1207-1213.

Svendsen, A. 2000. Review: Lipase protein engineering. Biochim. Biophys. Acta., 1543(2): 223-238.

Thakur, S. 2012. Lipases, its sources, Properties and Applications: A Review. Int. J. Sci. Eng. Res., 3(7): 1-29.

Tiwari, P., Upadhyay, M.K., Silawat, N. and Verma, H.N. 2011. Optimization and characterization of a thermo tolerant lipase from Cryptococcus albidus. Der pharma chem., 3(4): 501-508.

Toida, J., Kondoh, K., Fukuzawa, M., Ohnishi, K. and Sekiguchi, J. 1995. Purification and characterization of a lipase from Aspergillus oryzae. Biosci. Biotechnol. Biochem., 59(7): 11991203.

Ulker, S., Ozel, A., Colak, A. and Karaoglu, S.A. 2011. Isolation, production, and characterization of an extracellular lipase from Trichoderma harzianum isolated from soil . Turkish J. Biol., 35(5): 543-550.

Verma, N., Thakur, S. and Bhatt, A.K. 2012. Microbial Lipases: Industrial Applications and Properties (A Review). Int. Res. J. Biol. Sci., 1(8): 88-92.

$\mathrm{Yu}$, X.W., Wang, L.L. and Yan, X. 2009. Rhizopus chinensis lipase: Gene cloning, expression in Pichia pastoris and properties. J. Mol. Catal. B: Enzym., 57(1-4): 304-311.

Zhang, X. and Zhang, Y. 1982. Test use of alkaline lipase in degreasing of pigskin. Pige Keji, 40: 16-21.

Zhou, J., Chen, W.W., Jia, Z.B., Huang, G.R., Hong, Y., Tao, J.J. and Luo, X.B. 2012. Purification and Characterization of Lipase Produced by Aspergillus oryzae CJLU-31 Isolated from Waste Cooking Oily Soil. Am. J. Food Technol., 7(10): 596-608.

\section{How to cite this article:}

Arun Kumar Sharma, Vinay Sharma and Jyoti Saxena. 2016. A Review Paper on Properties of Fungal Lipases. Int.J.Curr.Microbiol.App.Sci. 5(12): 123-130.

doi: http://dx.doi.org/10.20546/ijcmas.2016.512.014 